\title{
Degradation of PAHs by Ligninolytic Enzymes of Irpex lacteus
}

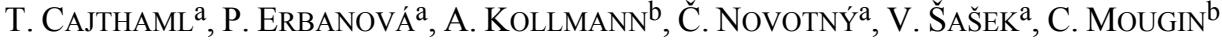 \\ ${ }^{a}$ Department of Ecology, Institute of Microbiology, Academy of Sciences of the Czech Republic, 14220 Prague, Czechia \\ e-mail cajthaml@biomed.cas.cz \\ bINRA, UR251 Physicochimie et Ecotoxicologie des Sols d'Agrosystèmes Contaminés, Versailles, 78026, France
}

\begin{abstract}
The ligninolytic fungus Irpex lacteus was shown as an efficient degrader of oligocyclic aromatic hydrocarbons (PAHs; 'polycyclic aromatic hydrocarbons') possessing 3-6 aromatic rings in complex liquid media. The strain produced mainly Mn-dependent peroxidase in media without pollutants. Activity of ligninolytic enzymes was higher in a N-limited medium. However, after contamination with PAHs (especially pyrene) the values increased and significant activity of Mn-independent peroxidase appeared in the complex medium. Other factors (such as the increase in nitrogen concentration or the presence of solvent(s) for dissolution of PAHs) had no effect. Cytochrome P-450 was detected in the microsomal fraction of biomass grown in the complex medium. The rate of PAH degradation was also affected by the presence of various combinations of PAHs. However, independently of the enzyme activities, anthracene was shown to have a positive influence on degradation of pyrene and fluoranthene.
\end{abstract}

\section{Abbreviations}

$\begin{array}{llll}\text { ANT } & \text { anthracene } & \text { CHR } & \text { chrysene } \\ \mathrm{BaA} & \text { benz }[a] \text { anthracene } & \text { FLT } & \text { fluoranthene } \\ \mathrm{BaP} & \text { benzo }[a] \text { pyrene } & \text { PHE } & \text { phenanthrene } \\ \text { BghiP } & \text { benzo }[g, h, i] \text { perylene } & \text { PYR } & \text { pyrene } \\ \text { LAC } & \text { phenol oxidase (laccase) } & \text { MIP } & \text { Mn-independent peroxidase } \\ \text { LiP } & \text { lignin peroxidase } & \text { MnP } & \text { Mn-dependent peroxidase } \\ \text { LNMM } & \text { low-nitrogen mineral medium } & \text { PAHs } & \text { oligocyclic aromatic hydrocarbons ('polycyclic aromatic hydrocarbons') }\end{array}$

MEG malt extract-glucose medium

PAHs and some of their derivatives are a class of serious environmental pollutants, which often have a high mutagenic and carcinogenic potential. One way of removing PAHs from the environment is bioremediation using various types of organisms (Cerniglia 1992; Cajthaml et al. 2001) including ligninolytic fungi (Bhatt et al. 2002; Šašek 2003). These fungi produce extracellular enzymes with low substrate specificity, making them suitable for degradation of various compounds. The ligninolytic system consists of three major enzymes: LiP (EC 1.11.1.14), MnP (EC 1.11.1.13) and LAC (EC 1.10.3.2). Purified ligninolytic enzymes were in vitro able to extensively degrade PAHs (Hofrichter et al. 1998; Baborová et al. 2006). Although the degradation process of PAHs by ligninolytic fungi has been widely studied, involvement of the enzymes in the in vivo degradation remains unclear. Several papers (Sack and Günther 1993; Yadav and Reddy 1992; Novotný et al. 1997; Schutzendubel et al. 1999) put in doubt a direct correlation between the activity of ligninolytic enzymes and degradation of xenobiotic aromates. Therefore Field et al. (1993) and Šašek (2003) suggested that other "unidentified" enzymes must be involved in the oxidation of pollutants.

In ligninolytic fungi, similarly to other microorganisms (Stündl et al. 1998; George and VanEtten 2001), P-450 was also found and its participation in the degradation of PAHs was proved (Bezalel et al. 1996; Cerniglia et al. 1992). Despite the fact that the role of ligninolytic enzymes in destruction of aromatic pollutants has not been elucidated completely, the ligninolytic fungi undoubtedly represent powerful prospective tool for soil bioremediation (Lang et al. 1996; Bhatt et al. 2002; Novotný et al. 2004; Šnajdr and Baldrian 2006, 2007).

The aim of this paper was to investigate PAH biodegradation by the ligninolytic fungus Irpex lacteus (1) by stimulation of ligninolytic enzyme activities by PAHs, (2) by affecting the production of different enzyme systems with various culture media, and (3) by changing the degradation rate of individual pollutants by using their mixtures. These factors are considered to play an important role in elucidation of the degradation process. 


\section{MATERIALS AND METHODS}

Chemicals. Anthracene, phenanthrene, pyrene, fluoranthene, chrysene, benz $[a]$ anthracene, benzo$[a]$ pyrene and benzo[ $g, h, i]$ perylene (Fluka, Germany) were used (Table I); they were applied without further purification to prepare stock solution in $\mathrm{HCONMe}_{2}$. All solvents were purchased from Merck (Germany) and were of analytical grade, trace analysis quality or gradient grade, other chemicals were from Sigma (France).<smiles>c1ccc2cc3ccccc3cc2c1</smiles>

ANT anthracene<smiles>c1ccc2c(c1)ccc1ccccc12</smiles>

PHE phenanthrene<smiles></smiles>

PYR<smiles>c1ccc2c(c1)-c1cccc3cccc-2c13</smiles>

FLT fluoranthene<smiles>c1ccc2c(c1)ccc1c3ccccc3ccc21</smiles>

CHR chrysene<smiles>c1ccc2cc3c(ccc4ccccc43)cc2c1</smiles>

$\mathrm{BaA}$ benz[a]anthracene

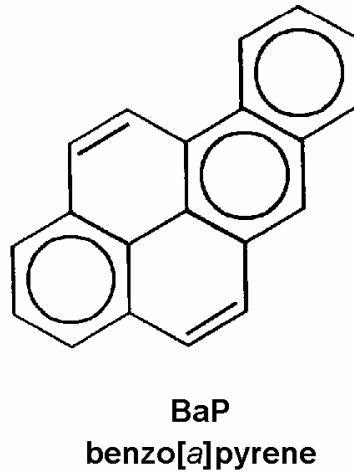

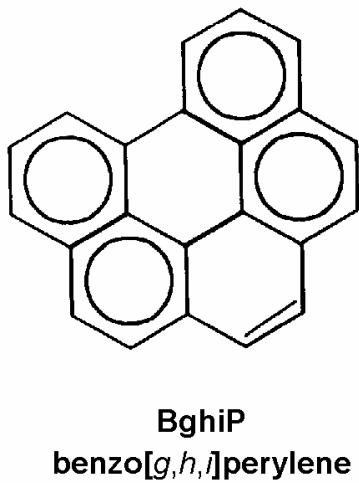

Culture conditions. Static 20-mL cultures of Irpex lacteus (Fr.:Fr.) Fr., strain 617/93 were incubated in 250-mL Erlenmeyer flasks in pentuplicates at $28^{\circ} \mathrm{C}$. The nutrient liquid media were used: LNMM containing $2.4 \mathrm{~mol} / \mathrm{L}$ diammonium tartrate (Vyas et al. 1994), complex MEG containing (per L) $5 \mathrm{~g}$ malt extract broth (Oxoid, UK) and $10 \mathrm{~g}$ glucose (Novotný et al. 2000). The liquid cultures were inoculated with a suspension of homogenized, 1-week grown mycelium $(5 \%, V / V)$. In the degradation experiments the media were supplemented with the corresponding PAH at the time of inoculation. The cultures were spiked with a solution of the PAH in $\mathrm{HCONMe}_{2}(150 \mu \mathrm{L})$. The final amount of each PAH was $0.5 \mathrm{mg}$ per flask.

During incubation the samples were harvested up to $50 \mathrm{~d}$. Degradation was performed in the simultaneous presence of PAHs included in the mixtures and also with the individual compounds or their combinations (to clarify their induction and/or inhibition effects). The abiotic controls were performed using 1-week grown mycelium killed by autoclaving.

Enzyme determination. LiP was assayed with veratryl alcohol as the substrate; MnP was determined with 3-dimethylaminobenzoic acid; 3-methyl-2-benzothiazoline hydrazone as the chromogen (Novotný et al. 1997). LAC was estimated with 2,2'-azino-bis(3-ethylbenzothiazoline-6-sulfonic acid) as the substrate (NikuPaavola et al. 1988). MIP was calculated from the peroxidase activity of MnP assay detected in the absence 


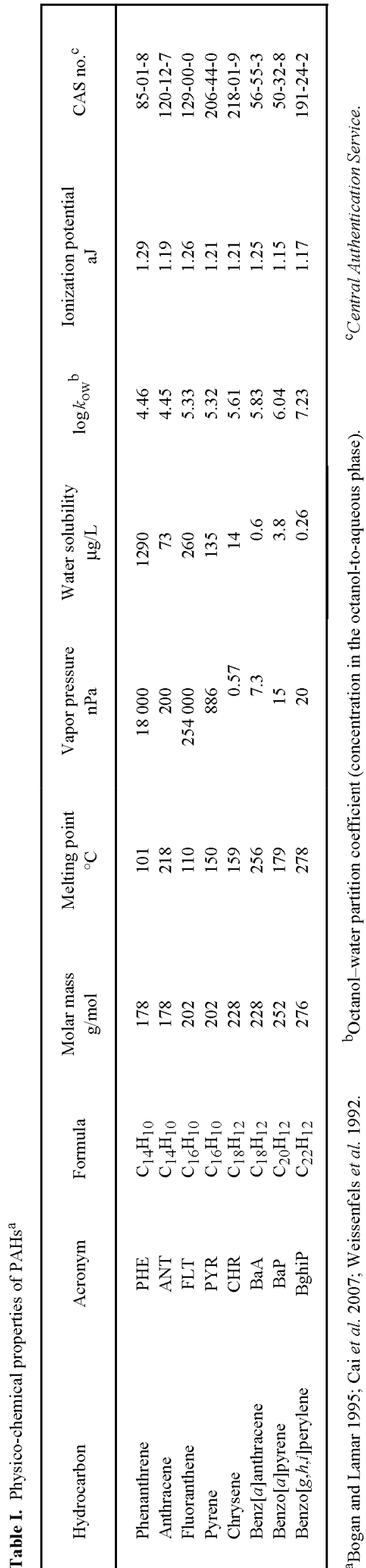

of $\mathrm{Mn}^{2+}$ ions (Novotný et al. 1997). One unit of enzyme produced $1 \mathrm{mmol}$ of the reaction product per min under the assay condition at room temperature.

Microsomal fractions were isolated from 7-d-old cultures (Mougin et al. 1997). Briefly, the cultures kept for $1 \mathrm{~h}$ at $4{ }^{\circ} \mathrm{C}$ were filtered, the biomass was washed with cold potassium phosphate buffer $(0.1 \mathrm{~mol} / \mathrm{L}, 50 \mathrm{~mL}, \mathrm{pH} 7.2)$, and disrupted in a Virtis 45 blender at $375 \mathrm{~Hz}$ in phosphate buffer $(30 \mathrm{~mL})$ supplemented with glycerol $(200 \mathrm{~g} / \mathrm{L})$ and bovine serum albumin $(1.5 \mathrm{~g} / \mathrm{L})$. $3 \times 10$ - and $2 \times 15$-s bursts were separated by 20 -s cooling periods in $1 \mathrm{~min}$. The crude homogenate was filtered and centrifuged $(1000 \mathrm{~g}, 15 \mathrm{~min})$. The supernatant was centrifuged (10000 $g$, $15 \mathrm{~min}$, and $100000 \mathrm{~g}, 90 \mathrm{~min}$ ), the supernatant being referred to as the cytosolic fraction. The pellets were then suspended in buffer $(10 \mathrm{~mL})$ and centrifuged again $(100000 \mathrm{~g}, 90 \mathrm{~min})$. The washed pellets, resuspended in phosphate buffer $(0.1 \mathrm{~mol} / \mathrm{L}$, $3 \mathrm{~mL})$ containing glycerol $(300 \mathrm{~g} / \mathrm{L})$, EDTA $(0.1 \mathrm{mmol} / \mathrm{L})$ and reduced glutathione $(0.1 \mathrm{mmol} / \mathrm{L})$, were referred to as the microsomal fraction. Both fractions were stored for up to 2 weeks at $-80{ }^{\circ} \mathrm{C}$ until used. Protein content was estimated using the BioRad kit for protein assay. Cytochrome P-450 was determined in both cytosolic and microsomal fractions using CO-binding spectra (Omura and Sato 1964).

Sample preparation and chemical analysis. The whole content (mycelium with the liquid) of each sample was homogenized with Ultraturrax-T25 (Janke \& Kunkel IKA-Labortech$n i k$, Germany), acidified to $\mathrm{pH} \approx 2$ and then extracted with five $10-\mathrm{mL}$ portions of ethyl acetate. The extracts were dried with disodium sulfate and concentrated with a rotary evaporator. To enable HPLC analysis, an aliquot of the extract was mixed with acetonitrile $1: 10(V / V)$ and the mixture was used for injection. The degradation of PAHs was measured using a HPLC system (Waters 2695 Separations Module) equipped with a diode-array detector (Waters 2996). An isocratic program was applied with acetonitrile-water 9:1 $(V / V)$ and PAHs were determined at $254 \mathrm{~nm}$; they were separated on a LichroCart-PAH column filled with LichroSphere $(250 \times 5 \mathrm{~mm}$, particle $\varnothing 5 \mu \mathrm{m}$; Merck, Germany).

\section{RESULTS AND DISCUSSION}

Degradation of individual PAHs with respect to culture conditions. The amounts of PAH (namely ANT, PHE, PYR, FLT) in the cultures decreased (Table II). Because analysis was performed on the whole cultures, it was assumed that biodegradation occurred. However, PYR and FLT appeared to be degraded only in MEG medium, whereas ANT and PHE disappeared in LNMM medium. Due to ionozation potential value PHE and FLT should not be degraded by ligninolytic system (Bogan and Lamar 1995) and the biodegradation could be attributed to cytochrome P-450. However, in the presence of intermediates (e.g., glutathione) PHE and FLT can also be decomposed with purified MnP (Baborová et al. 2006).

To elucidate the possible effect of nitrogen amount in the medium, the level of degradation was determined in modified media. LNMM was enriched with a 10 -fold concentration of diammonium tartrate and MEG was prepared with malt extract con- 
taining mycological peptone (Oxoid, UK). Under the modified conditions we did not observe any change of the extent of degradation (not shown). This finding confirms that (in I. lacteus cultures) the ligninolytic conditions elicited by low nitrogen concentration have limited importance for PAH biodegradation (Kotterman et al. 1994).

Table II. Degradation of PAHs (recovery, \%) by I. lacteus in MEG and LNMM media ${ }^{\text {a }}$

\begin{tabular}{|rlrrrr|}
\hline Days & Medium $^{\mathrm{b}}$ & \multicolumn{1}{c}{ ANT } & PHE & PYR & FLT \\
\hline 50 & control & $76.2 \pm 3.6$ & $93.5 \pm 2.5$ & $84.0 \pm 3.1$ & $80.8 \pm 0.9$ \\
6 & MEG & $62.4 \pm 4.7$ & $80.6 \pm 5.0$ & $84.4 \pm 6.8$ & $86.3 \pm 4.9$ \\
20 & & $13.4 \pm 2.3$ & $40.1 \pm 2.7$ & $42.2 \pm 4.5$ & $60.0 \pm 2.4$ \\
50 & & $0.8 \pm 0.7$ & $7.7 \pm 2.6$ & $4.7 \pm 3.8$ & $46.0 \pm 2.4$ \\
6 & LNMM & $73.0 \pm 3.1$ & $99.4 \pm 4.5$ & $97.9 \pm 2.9$ & $98.1 \pm 3.7$ \\
20 & & $45.5 \pm 4.0$ & $82.2 \pm 3.0$ & $93.8 \pm 1.6$ & $93.5 \pm 3.2$ \\
50 & & $22.3 \pm 8.6$ & $9.7 \pm 0.8$ & $83.0 \pm 2.7$ & $79.0 \pm 2.0$ \\
\hline
\end{tabular}

${ }^{\mathrm{a} A N T}$ - anthracene, PHE - phenanthrene, PYR - pyrene, FLT - fluoranthene.

${ }^{\mathrm{M}} \mathrm{MEG}$ - malt extract-glucose medium, LNMM - low-nitrogen mineral medium.

Enzyme production with respect to culture conditions. Activity of ligninolytic enzymes reached maximal values after 15-20 d (Table II). In contrast to results of the degradation, the enzyme activity values were found to be higher in LNMM without PAH supplementation. The addition of the ANT, FLT, PHE, and PYR mixture resulted in increased ligninolytic enzyme activity and (in the case of MEG medium) a significantly higher activity of MIP appeared; it indicates a possible role of MIP in the degradation of PYR and FLT, especially when the concentration of Mn (necessary for proper MnP function) was $25 \times$ higher in LNMM compared to MEG medium (data not shown).

For the influence of individual compounds on the enzyme activity in MEG see Table III. Particularly in the case of PYR, stimulation of MnP and MIP activities was observed. The solvent used ( $\left.\mathrm{HCONMe}_{2}\right)$ showed no effect on the enzyme activities (not shown). In some papers (Yang et al. 2003; De Souza et al. 2004; Kollmann et al. 2005; Canas et al. 2007), one-ring compounds were demonstrated to act as inducers of ligninolytic system. Such compounds were also showed to be products of PAH degradation (Cajthaml et al. 2002, 2006). The selection of fungal strains for bioremediation applications should probably not be based only on the enzyme activities or ability to degrade some screening model substrates, e.g., poly R-478 (Šašek 2003).

Table III. Maximal activity (U/L) of ligninolytic enzymes of I. lacteus in liquid nutrient media and in the presence of PAHs

\begin{tabular}{|clrrrr|}
\hline \multirow{2}{*}{ Medium $^{\mathrm{a}}$} & PAH $^{\mathrm{b}}$ & MnP & MIP & LiP & Lac \\
\hline \multirow{2}{*}{ LNMM } & none & 273 & 10 & 20 & 5 \\
& mixture & 459 & 91 & 42 & 12 \\
MEG & none & 120 & 9 & 3 & 6 \\
& mixture & 260 & 397 & 44 & 11 \\
& ANT & 66 & 29 & 21 & 5 \\
& PHE & 120 & 152 & 7 & 8 \\
& PYR & 239 & 34 & 26 & 6 \\
\hline
\end{tabular}

${ }^{\text {a }}$ LNMM - low-nitrogen mineral medium, MEG - malt extract-glucose medium.

${ }^{\mathrm{b}} \mathrm{ANT}$ - anthracene, PHE - phenanthrene, PYR - pyrene, FLT - fluoranthene.

The presence of CHR, BaA, BaP, or BghiP did not affect the ligninolytic enzyme activity (not shown); it can be explained, e.g., by their lower solubility that influences significantly availability of the compounds for organisms (Semple et al. 2003).

Cytochrome P-450 (taking part in degradation of some PAHs; Bezalel et al. 1996), was not detected in cultures of I. lacteus grown in LNMM, however, $780 \mathrm{pmol} / \mathrm{mg}$ protein was estimated in the microsomal 


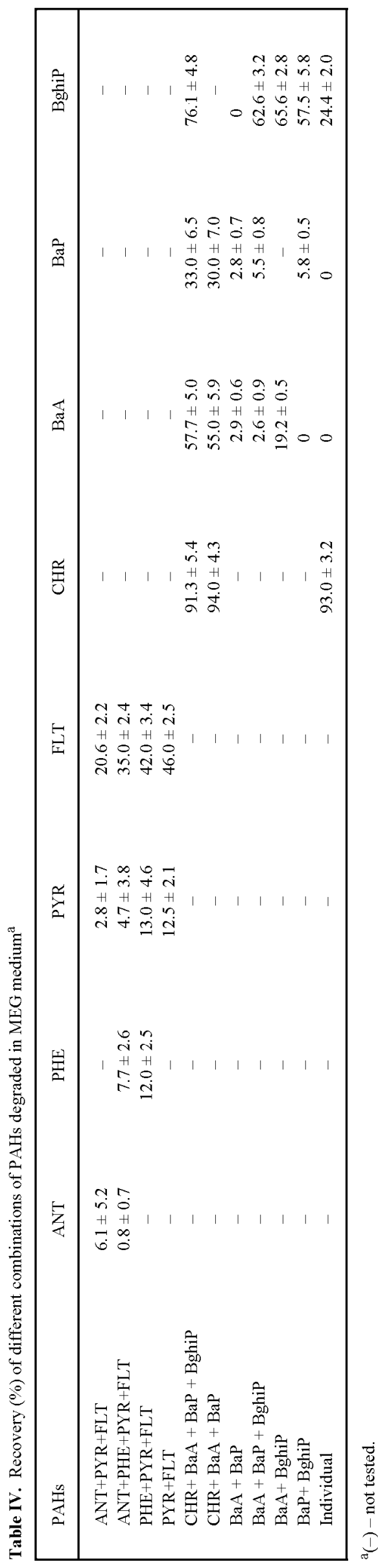

fraction of biomass grown in MEG medium. For the CObinding spectrum (that proves the presence of active P-450) see Fig. 1. Much lower activity was detected in the cytosolic fraction ( $4.8 \mathrm{pmol} / \mathrm{mg}$ protein). We detected (Cajthaml et al. 2002) at I. lacteus several novel intermediates of PAHs degradation, probably connected with the participation of P-450 in their biodegradation. Nevertheless, using PAHs as substrates, no P-450 activity was detected in microsomal or cytosolic fractions regardless of the culture conditions.

Degradation of PAH mixtures. I. lacteus degraded efficiently BaA, BaP and BghiP in MEG medium (Table IV), CHR being not degraded in any case. A possible explanation may be its high ionization potential (see Table I) that can negatively affect one-electron oxidation performed by extracellular ligninolytic system of the fungus (Bogan and Lamar 1995). Particularly ANT had a positive effect on the degradation rate of PYR and FLT, however, independently of the activity of ligninolytic enzymes. On the other hand, CHR, despite its low water solubility, negatively affected the degradation rate of other PAHs.

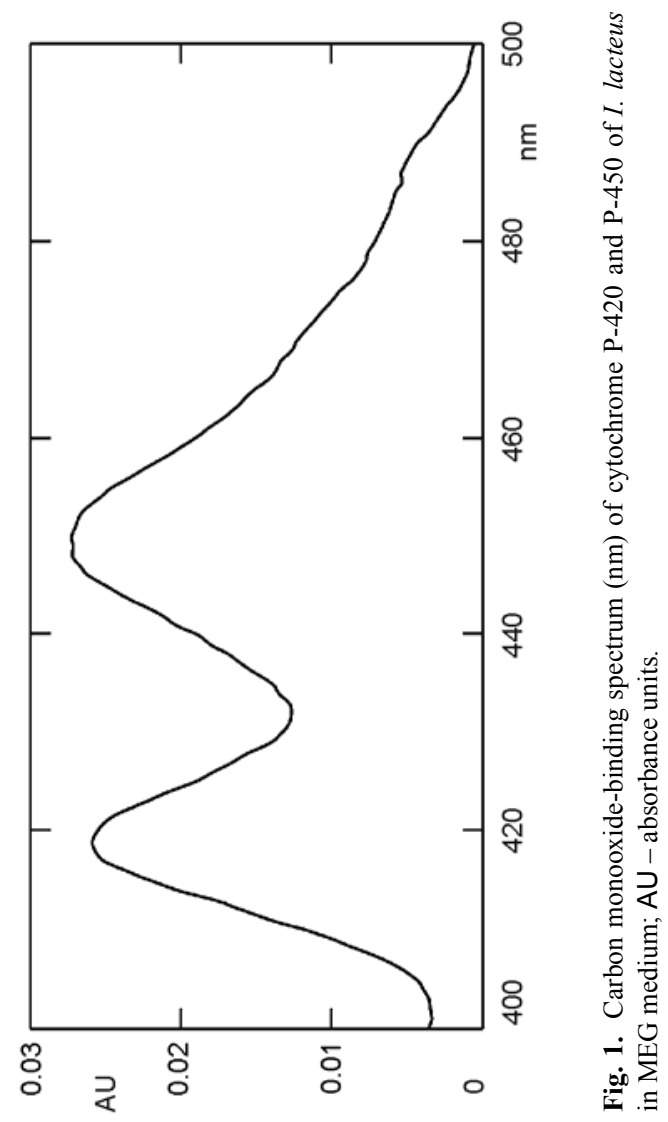

This work was supported by grants nos. 2B06156, 1P05ME827 and LC06066 (all Ministry of Education, Youth and Sports of the Czech Republic), no. 206/03/P078 (Grant Agency of the Czech Republic), nos. IAA6020411 and KJB600200613 (Grant Agency of the Academy of Sciences of the Czech Republic), Institutional Research Concept no. AV0Z50200510, and French Barrande Project no. 07491ND. 


\section{REFERENCES}

Baborová P., Möder M., Baldrian P., CAJThamlová K., CAJThaml T.: Purification of a new manganese peroxidase of the whiterot fungus Irpex lacteus, and degradation of polycyclic aromatic hydrocarbons by the enzyme. Res.Microbiol. 157, 248-253 (2006).

Bezalel L., Hadar Y., Fu P.P., Freeman J.P., Cerniglia C.E.: Metabolism of phenanthrene by the white-rot fungus Pleurotus ostreatus. Appl.Environ.Microbiol. 62, 2547-2553 (1996).

BhATT M., CAJTHAML T., ŠAŠEK V.: Mycoremediation of PAH-contaminated soil. Folia Microbiol. 47, 255-258 (2002).

BOGAN B.W., LAMAR R.T.: One-electron oxidation in the degradation of creosote polycyclic aromatic hydrocarbons by Phanerochaete chrysosporium. Appl.Environ.Microbiol. 61, 2631-2635 (1995).

CAI Q.-Y., MO C.-H., WU Q.-T., ZENG Q.-Y., KATSOYIANNIS A., FÉRARD J.-F.: Bioremediation of polycyclic aromatic hydrocarbons (PAHs)-contaminated sewage sludge by different composting processes. J.Hazard.Mater. 142, 535-542 (2007).

CAJTHAML T., PACÁKOVÁ V., ŠAŠEK V.: Microbial degradation of polycyclic aromatic hydrocarbons. (In Czech) Chem.Listy 95, 404410 (2001).

CAJTHAML T., MÖDER M., KAČER P., ŠAŠEK V., POPP P.: Study of fungal degradation products of polycyclic aromatic hydrocarbons using gas chromatography with ion trap mass spectrometry detection. J.Chromatogr. A 974, 213-222 (2002).

CAJTHAML T., ERBANOVÁ P., ŠAŠEK V., MÖDER M.: Breakdown products on metabolic pathway of degradation of benz[ $a]$ anthracene by a ligninolytic fungus. Chemosphere 64, 560-564 (2006).

CANas A.I., AlCAlde M., Plou F., Martinez M.J., Martinez A.T., CAMARero S.: Transformation of polycyclic aromatic hydrocarbons by laccase is strongly enhanced by phenolic compounds present in soil. Environ.Sci.Technol. 8, 2964-2971 (2007).

CERNIGLIA C.E.: Biodegradation of polycyclic aromatic hydrocarbons. Biodegradation 3, 351-368 (1992).

Chung N.H., LeE I.S., Song H.S., BANG W.G.: Mechanisms used by white-rot fungus to degrade lignin and toxic chemicals. J.Microbiol.Biotechnol. 10, 737-752 (2001).

FIELD J.A., DE JONG E., COSTA G.F., DE BONT J.A.M.: Screening for ligninolytic fungi applicable to the biodegradation of xenobiotics. Trends Biotechnol. 11, 44-49 (1993).

GeORGE H.L., VANETTEN H.D.: Characterization of pisatin-inducible cytochrome P-450s in fungal pathogens of pea that detoxify the pea phytoalexin pisatin. Fungal Genet.Biol. 33, 37-48 (2001).

HOFRICHTER M., SCHEIBNER K., SCHNEEGASS I., FRITSCHE W.: Enzymatic combustion of aromatic and aliphatic compounds by manganese peroxidase from Nematoloma frowardii. Appl.Environ.Microbiol. 64, 399-404 (1998).

Kollmann A., Boyer F.D., Ducrot P.H., KerhoAs L., Jolivalt C., TOUTON I., Einhorn J., Mougin C.: Oligomeric compounds formed from 2,5-xylidine (2,5-dimethylaniline) are potent enhancers of laccase production in Trametes versicolor ATCC 32745. Appl.Microbiol.Biotechnol. 68, 251-258 (2005).

KotTerman M.J.J., HeEssels E., DE JONG E., FiELD J.A.: The physiology of anthracene biodegradation by the white-rot fungus Bjerkandera sp. strain BOS55. Appl.Microbiol.Biotechnol. 42, 179-186 (1994).

LANG E., Nerud F., NOVOTNÁ E., ZADRAŽIL F., MARTENS R.: Production of ligninolytic exoenzymes and ${ }^{14} \mathrm{C}$-pyrene mineralization by Pleurotus sp. in lignocellulose substrate. Folia Microbiol. 41, 489-493 (1996).

Mougin C., LAugero C., Asther M., Chaplain V.: Biotransformation of $s$-triazine herbicides and related degradation products in liquid cultures by the white rot fungus Phanerochaete chrysosporium. Pestic.Sci. 49, 169-177 (1997).

Niku-PaAvola M.L, KARHUnen P, SAlola P., FAunKo V.: Ligninolytic enzymes of the white-rot fungus Phlebia radiata. Biochem.J. 254, 877-884 (1988).

NovotnÝ Č., VyAS B.R.M., ERBANOVÁ P., KUBÁtOVÁ A., ŠAŠEK V.: Removal of PCBs by various white-rot fungi in liquid culture. Folia Microbiol. 42, 136-140 (1997).

Novotný Č., ERbanová P., CAJThaml T., Rothschild N., Dosoretz C., ŠAŠEK V.: Irpex lacteus, a white-rot fungus applicable to water and soil bioremediation. Appl.Microbiol.Biotechnol. 54, 850-853 (2000).

Novotný Č., Svobodová K., ERbanová P., CAJThaml T., KASINATH A., LANG E., ŠAŠEK V.: Ligninolytic fungi in bioremediation: extracellular enzyme production and degradation rate. Soil Biol.Biochem. 36, 1545-1551 (2004).

OMURA T., SATO R.: The carbon monoxide-binding pigment of liver microsomes. II. Solubilization, purification and properties. J.Biol. Chem. 239, 2370-2378 (1964).

SACK U., GÜNTHER T.: Metabolism of PAH by fungi and correlation with extracellular enzymatic activities. J.Basic Microbiol. 33, 269-277 (1993).

ŠAŠEK V.: Why mycoremediation has not yet come into practice, pp. 247-266 in V. Šašek, J. Glaser, P. Baveye (Eds): The Utilization of Bioremediation to Reduce Soil Contamination: Problems and Solutions. Kluwer Academic Publishers, Dordrecht 2003.

SCHUTZENDUBEL A., MAJCHERCZYK A., JohANNES C., HÜTTERMANN A.: Degradation of fluorene, anthracene, phenanthrene, fluoranthene, and pyrene lacks connection to the production of extracellular enzymes by Pleurotus ostreatus and Bjerkandera adusta. Internat.Biodeter.Biodegr. 43, 93-100 (1999).

SEMPLE K.T., MORRISS A.W.J., PATON G.I.: Bioavailability of hydrophobic organic contaminants in soils: fundamental concepts and techniques for analysis. Eur.J.Soil Sci. 54, 809-818 (2003).

ŠNAJDR J., BALDRIAN P.: Production of lignocellulose-degrading enzymes and changes in soil bacterial communities during the growth of Pleurotus ostreatus in soil with different carbon content. Folia Microbiol. 51, 579-590 (2006).

ŠNAJDR J., BALDRIAN P.: Temperature affects the production, activity and stability of ligninolytic enzymes in Pleurotus ostreatus and Trametes versicolor. Folia Microbiol. 51, 498-502 (2007).

De Souza C.G.M., Tychanowicz G.K., DE Souza D.F., Peralta R.M.: Production of laccase isoforms by Pleurotus pulmonarius in response to presence of phenolic and aromatic compounds. J.Basic.Microbiol. 44, 129-136 (2004).

STÜNDL U.M., SCHMIDT I., SCHELlER U., SCHMID R., SCHUNCK W.H., SCHAUER F.: Purification and characterization of cytosolic cytochrome P-450 forms from yeasts belonging to the genus Trichosporon. Arch.Biochem.Biophys. 357, 131-136 (1998).

VYAS B.R.M., BAKOWSKI S., ŠAŠEK V., MATUCHA M.: Degradation of anthracene by selected white-rot fungi. FEMS Microbiol.Ecol. 14, 65-70 (1994)

WEISSENFELS W.D., KLEWER H.-J., LANGHOFF J.: Adsorption of polycyclic aromatic hydrocarbons (PAHs) by soil particles: influence on biodegradability and biotoxicity. Appl.Microbiol.Biol. 36, 689-696 (1992).

YADAV J.S., REDDY C.A.: Non-involvement of lignin peroxidases and manganese peroxidases in 2,4,5-trichlorophenoxyacetic acid degradation by Phanerochaete chrysosporium. Biotechnol.Lett. 14, 1089-1092 (1992).

Yang Q.X., Yang M., Pritsch K., Yediler A., Hagn A., Schloter M., KetTrup A.: Decolorization of synthetic dyes and production of manganese-dependent peroxidase by new fungal isolates. Biotechnol.Lett. 25, 709-713 (2003). 